\title{
Christianity in World History
}

L.onden, 1964, 487 bl. - Deur A. Th. van Lecuwen.

Professor $\mathrm{H}$. Kraener, die onlangs ontslape leermeester en gecslelike vader van dr. Van Leeuwen het in die roorwoord van hierdie bock dit heeltenal tereg as 'n evenement gekaraktiseer. Die werk getuig van groot geleerdheid. belesenheid en briljantheid en plek-plek ook van groot oorspronklikheid. Dit open in verskillende opsigte nuwe insigte en indrukwekkende perspektiewe oor die roeping tot die evangelieverkondiging in 'n planetêre wêreld. Dit kom ook as 'n groot uitdaging tot die Christendom.

Daar is dan ook groot bewondering vir hierdie werk, maar vanwee te veel onnoukeurighede. foute en onbewese en gewaigde stellinge word dit ook skerp gekritisear, o.a. deur prof. H. de Vos in die Nederlandse Teologiese Tydskrif, Junic 1965. p. 343 e.v.

Tog doen hierdie tckortkoming: nic groot afbreuk aan die werk as geheel nie, want die outeur skryf oor die geheel geneem met groot kennis van sake en hy het op een of twee uitsonderings na die beste en mees resente bronne op die verskillende betrokka terreine van die baie breë stof geraadpleeg. Waar :o in omvangryke onderwerp met sulke verskillende uiteenlopende tcmas bshandel word, kan dit in 'n sekere mate verskoon word as die skrywer hier en daar nie ten volle beantwoord aan alle wetenskaplike veraistes nie.

Ons wil nie by allerlei details stil staan nic maar sal dic hoofsaak waaroor dit gaan. die eintlike tema van die bock nader in oinskou neem en beoordeel. Dit word duidelik aangegee in die titel waaruit blyk dat dit gaan oor die verhouding van die voortgang van die Christendom en die wêreldgeskiedenis.

Die skrywer wil nie weet van 'n Westerse superioriteitsgevoel nie. Daarom pleit hy vir 'n wîreld-sentriese i.p.v. in Europa-sentriese geskiedenisbeskouing. Tog wil hy niks weet van in Europese defaitisme asof die Weste eintlik afgedoen het en die Ooste nou die leiding moet oorneen. Hy wil laat sien dat die Evangelie in sy gang deur die wêreld 'n heel besondere gestalte aangeneem het in die Westerse kultuur, en hy beweeg daarom in sy werk tussen hierdie twee pole van evangelie- en kultuurvooruitgang. Wal beide hulle wortels in die Weste het, om dan uiteindelik hierdie twee prosesse en deurwerkinge met mekaar te laat verstrengel in 'n esgatologiese rigting. Hierdeur skep hy tog weer die indruk van 'n Furopese superioriteitsgevoel. veral waar hy konstateer dat daar in die nuwe wêreld nie plek sal wees vir die nie-christelike godsdienste nie en die hele wêreldontwikkeling volgens hom in die rigting van een Westers georiëntedrde kultuurpatroon gaan.

Hy soek die wortels van die Westerse beskawing in die geskiedenis van die volk Israel soos dit beskryf word in die (Ou lestament en soos dit verder in die volheid van die tyd deur Christus vervul is. Hierin lê die wortels van die evangelie-uitbreiding sowel as van die Westerse kultuurverspreiding. 
Hy vind in die (Ju lestament in skerp reaksie teen en in radikale ontmitologisering van die naturalistiese monisme van die heidendom. Teenoor die lotalitere samehangsgedagte en die ineenstrengeling van die goddelike en dic kreatuurlike laat die Ou Testament God sien as die lewende Here en Skepper van alles. en teenoor die heidense opvatling dat alles beweeg in $n$ sikliese gang wat telkens weer by die begin cindig. stel die Ou Testament God as die Here van die geskiedenis wat Israel geplaas het op die weg van sý doel met die skepping. In hierdie verband open die skrywer veral oor (jen. 1-11 soms verrassend nuwe insigte. hoewel ook hier agter een en ander 'n vraagteken geplaas moet word.

In die Nuwe Testament word die lyn verder deurgetrek. In Jesus Christus word die hele geskiedenis van die volk Israel verteenwoordig. saamgevat en vervul. Hy is die voleinding van die geskiedenis. Tog bly die vervulling op elke onderdeel nog uitstaande. Die evangelie moet in die hele wêrell verkondig word tot 'n getuienis vir al die nasies: en dan sal die einde kom (Matth. 24:14). Die verkondiging wat die einde van die tyd irilui, is dus tewens die begin van die Christelike tydpurk. Die wereldgeskiedenis word opgeneem in die ..laasle dae" en kom so in engatologiese lig le staan. Hierdie esgatologiese gebeurtenis van die volheid van die tyd is tewens die begin van die geskiedenis van die Christendem.

Dil dan is die een pool waarheen die skrywer beweeg. Die ander een het betrekking op die kultuur-antropologiese aspak in die wêreldgeskiedenis. Aan die Christelike lydperk het voorafgegaan in $6,0(0)($ (?) jarige neolities-agrariese lydperk wal deur die ,.ontokratiese patroon" gekenmerk was, terwyl die geskiedenis nou staan in die teken van die ..tegnokratiese patroon". Onder die cerste verstaan die skrywer die heerskappy(-krasie) van die synde (onto) en onder die laaste die heerskappy(-krasie) van die legnick (tegno-). In die eersgenoende geval regeer die mens nie oor die kreatuurlike werklikheid nie maar is daaraan onderwerp. Die natuur word vergoddelik en die goddelike word verkreatuurlik. Daar is $n$ dwingende mag in die natuurorde wat die ganse menslike lewe aan bande lê.

Met so 'n patroon is daar nie die moontlikhede van ware wetenskap en vooruitgang nie. Die hele lewe word vanaf die geboorte tot die dood vasgelê in 'n vaste tradisionele patroon, en in die politieke organisasie word die gesagsdraers baie nou met die godsdiens en die bonatuurlike verbind.

in Soortgelyke hinding van die lewe was daar ook in die corpus rhristimium van die Middeleete. maar hier is die ontokratiese patroon deurbreek veral deur dic aksent wat op die teokratiese gedagte gelé is.

llit die boom van die (hristendom. soos dit in die Weste wortel geskiet het. groei daar nou as vrugte die sending- asook die kultuurvoortgang in die nuwe wëreld. waarin die moderne geskiedenis as dit ware 'n eksponent van die koms van die konikryk van God is. Die revolusioncre dinamick is gedurig werksaam in die Westerse beskawing 
en dit is steeds in beweging as gevolg van die geskiedenis wat oor Sion tot ,die eindes van die aarde" reik.

Die huidige tegnokratiese tydperk kan nie sonder hierdie beweging gedink word nie, want hier agter lê die geloof dat die wêreld die skepping van God is. Die tegnokratiese ontwikkeling deurbreek die ontokratiese patroon dwars deur die wiseld en die lewe word oral gedesakraliseer en gesekulariseer. Dit is in vrug van die Christelike boom.

Daarom moet die tegniese on:wikkeling en die sekularistiese lewenspatroon ook positief gewaardier word. Daar moet egler onderskei word tussen sekularisasie en sekularisme. Onder sekularisasie word verstaan 'n desakralisering en versakeling wat neerkom op 'n bevryding uit die ontokratiese patroon. Sekularisme eg.er is in geslote en verabsoluteerde ideologic. dic bon:uurlike word uit die lewe weggesyfer maar dit beweeg self in die rigting van in heidense of nihilistiese totalitarisme met in nuwe soort ontokratiese patroon. soos reeds nou tot openbaring kom in die kommunisme. Sekularisme moet veroordeel word, maar solank dit nie verabsolufeer word nie, moet sekularisasie aangemoedig word. Daarin moet gesien word ook lekens van die koms van die koninkryk van God.

Ons kan baic waardering hî vir die grootse taak wat die skrywer aangepak het en op so in deurdringende en omvallende wyse deurgevoer het. Hy leer ons on die huidige wireld ernstig op te neem. om die goeic in die tegniese en wetenskaplike ontwikkeling en die bevryding wat deur die sekularisasie leweeg gebring is, te waardecr. Sy boek is 'n waarskuwing om nie die sekulere lewe te verkerklik of aan "n ,,verkrampte" tradisionele patroon te onderwerp nie. Ons word tot vryheid geroep en nie tot in ou of nuwe soort slawerny nie, sê Paulus. Die Here het die magte oorwin en ons hoef dus nie meer daarvoor bevrees te wees nie. Dit is ook Sy wil dat die mens tol die hoogs moontlike peil ontwikkel. Vryheid en vooruitgang, vrede en welvaart - ook dit is openbaringe van die koms van die koninkryk van God.

Die skrywer prikkel ons ook om ons verder te besin oor die verhouding van die wêreldgeskiedenis en die uitbreiding van die koninkryk van God. Hy toon voorts op in treffende wyse aan hoe dat die Ou Testament die heidendom ontmitologiseer en hy sê soms dinge wat, soos reeds opgemerk is, getuig van groot oorspronklikheid. Hiervan is o.a. voorbeelde sy opmerkinge oor . die eindes van die aarde", oor die Islam en oor die parallellic tussen Islam en kommunisne.

Ten spyte van al die voortreflikhede en bociende inhoud word ons egter telkens geprikkel lot teenypraak en ons lê die boek tuiteindelik met 'n sug van teleurstelling neer. Die grondfout meen ons lê in die eensydige en optimistiese beskouinge oor die tegnokrasie en sekularisasie. Sekularisasie moet volgens hom alleen veroordeel word as dit oorhel na verabsolutering. Dit is egter baie neer ambivalent as wal die skrywer te kenne wil gee. Die legnokrasie lei tot bevryding en 
vooruitgang maar kan ook die vernietiging van die mensheid deur die uitbarsting van die kernkrag teweeg bring. Sekularisasie hou nie net 'n neutrale versakeling in nie maar dit loop daarop uit dat God self uit die lewe geban word. Dit lei uiteindelik tot 'n godsdiens waar die Antichris op die troon sit.

Sekularisasie sonder meer bly altyd ambivalent of word heeltemal antiteties teenoor die waarheid van die Skrif. Tog moet ook die goeie. wat deur die algemene genade van God daarin aan die lig kom, op prys gestel word en selfs die Christelike lewe moet in 'n sekere sin hierby inpas. Vir die beoordeling daarvan moet ons terugkeer na die Skrif en, soos prof. H. Bergema en J. Verkuyl in hulle onderskeie inougurele redes opmerk, ook deeglik kennis neem van wat A. Kuyper. H. Bavinck en Berkouwer hieroor sê. Die Skrif ken nie die sekularisasie-begrip sonder meer nie. In die Skrif is daar die onttroning van die ontokrasie maar ook die intronisasie van Jesus Christus, die Kurios. die Pantokrator. Daar moet wees nie net die desakralisering van die lewe nie maar ook die heiliging van die tegniek en wetenskap aan God; nie net die ontgoddeliking van die natuur nie maar ook die heerlikheid van God in en deur sy algemene openbaring; nie net die vryheid deur die sekularisasie nie maar ook die vryheid in gebondenheid aan Christus.

Ons kan nie met Van L.eeuwen saamstem nie dat die tegnokrasie en sekularisasie 'n einde sal maak aan die nie-christelike godsdienste. Die werklikheid loënstraf hierdie profesie. want hoewel bv. die Oosterse religies hulle daarmee versoen. ondergaan hulle desnieteenstaande in vernuwing, en gedeeltelik as reaksie teen die sekularistiese tendense ontstaan daar nou oral onder die nie-Westerse volke 'n strewe na 'n nuw godsdienstige oriëntasie, wat reeds gestalte aangeneem het o.a. in die honderde sinkretistiese sektes in Suid-Afrika; daarbenewens kry ons ook nuwe ideologieë en uiteindelik selfs die aanbidding van die Antichris, want, soos Christus voorsê het, sal daar .,valse Christusse en valse profete opstaan en hulle sal tekens en wonders doen" (Mrk. 13:22). Solank God bestaan sal daar altyd godsdiens(te) wees. in (iodsdienslose tyd sal nooit aanbreek nie.

Ons kan verder nie soos die skrywer doen, aanneem dat die huidige tegniese vooruitgang en sekularisasie vanselfsprekende en direkte vrugte van die Christendom is nie, want selfs in die heidense kulture is daar latente moontlikhede in hierdie rigting, soos daaruit blyk dat reeds in die Skrif die lyn van ontwikkeling in die geslag van Kaïn loop en daar soos wel bekend is reeds lank voor die Christelike tydperk hö kultuurontwikkeling in China, Egipte, Babilonië, Mesopolamië ens. was. Die hoë peil van die huidige ontwikkeling moet toegeskryf word aan dic algemeen menslike potensialiteite in hierdie opsigte, hoewel die Christendom eerder as ander godsdienste hierin stimulerend kan wees.

Dit is wel waar dat, soos die skrywer sê. die sekularisasie ook esgatologiese betekenis het. maar daurvan kan nie 'n soort nuwe evangelic gemaak word nie. Dic engatologiese betekenis lê daarin dat die tyd van die wederkons van Christus nic alleen bepaal word deur 
die verkondiging tot aan die eindes van die aarde nie. maar. soos Kuyper tereg aangetoon het, ook deur die wetenskaplike en tegniese ontwikkeling. Eers wanneer die mens die hoogs moontlike peil van ontwikkeling hierin bereik het. sal die einde daar wees. (Ook hierin is daar egter ambivalensie, want enersyds is daar die ongelowige ontwikkelingsrigting wat lei tot die rypheid van die sonde en die koms van die Antichris en andersyds kan die gelowige tegnikus of wetenskaplike in sy aandeel in die ontwikkelingsgang sien die nadering van die koms van die koninkryk van God en tot openbaring bring in afskaduwing, 'n weerspieëling en antisipasie van die heerlikheid van die komende koninkryk, wanneer die eer en heerlikheid van die nasies in die nuwe Jerusalem ingebring sal word (Open. 21:26) en die hele aarde vol sal wees van die heerlikheid (Jes. 6:3) en van die kennis van God (Jes. 11:9).

Aan die ander kant word die gemeente deur die groeiende sekularisme gedwing tot ernstige besinning oor die belewing en uitkristalisering van die waarheid en die Christelike lewe in 'n wêreld waarin die godsdiens nie meer bepaal word deur tradisionele voorskrifte en bande en die publieke opinie nie.

Waar hierdie steunsels wegval. kan die sekularisasie tog ook tot 'n seën vir die gemeente wees, nl. daarin dat dit daardeur teruggewerp word op die Woord van God en die lewende band met en gelowige vertroue op Christus as die enigste vashouplek en anker vir 'n ware Christelike lewe van die gemeente as liggaam van Christus.

Ons kan in meer as een opsig dankbaar wees vir die boek van Van Leeuwen. Hy bied wel nie die oplossing van die problematiek rondom die sekularisasie-vraagstuk en van die verhouding van Sending en wêreldgeskiedenis nie maar sy boek is tog 'n belangrike bydrae hiervoor en hy laat ons ons opnutut besin oor ons roeping en taak in 'n gesekulariseerde wêreld. Oor die vraagstuk self sal daar egter teologies nog dieper en meer Skrifmatig gegrawe en verder voortgebou moet word.

H. du Plessis. 